\title{
DIFERENSIASI KONSEP PEREMPUAN TIGA ZAMAN: KAJIAN DEKONSTRUKSI JACQUES DERRIDA
}

\author{
Muakibatul Hasanah dan Robiatul Adawiyah \\ Universitas Negeri Malang \\ email: muakibatul.hasanah.fs@um.ac.id
}

\begin{abstract}
Abstrak
Novel sebagai representasi dari kehidupan nyata banyak mengangkat tema-tema yang selama ini berkembang di masyarakat. Salah satu tema yang menarik dan banyak diangkat adalah tema yang berhubungan dengan perempuan. Setiap penulis mempunyai cara tersendiri untuk membuat pembaca tetap tertarik dengan kisah yang disajikan. Hal itu dilakukan tidak hanya dengan penyajian jalan cerita yang berbeda, namun juga melakukan konstruksi yang berbeda-beda pada sosok perempuan sehingga setiap cerita menggambarkan citra perempuan yang berbeda pula. Penelitian ini bertujuan untuk mengidentifikasi perbedaan konsep perempuan dan memaparkan unsur aporia dalam Novel Sitti Nurbaya, Belenggu, dan Di Balik Kerling Saatirah. Pendekatan yang digunakan dalam penelitian ini adalah pendekatan dekonstruksi. Jenis penelitian yang digunakan adalah penelitian kualitatif. Data penelitian berupa kutipan dialog, monolog, dan narasi yang sesuai dengan fokus serta tujuan penelitian. Hasil penelitian ini menunjukkan bahwa terdapat perbedaan bentuk dekonstruksi konsep perempuan yang tergambar melalui penokohan Siti Nurbaya, Rohayah, dan Saatirah. Selain itu, melalui pembacaan dekonstruktif dapat ditemukan unsur aporia berupa paradoks, ironi, dan kontradiksi dalam ketiga novel tersebut.
\end{abstract}

Kata Kunci: diferensiasi, perempuan, dekonstruksi, aporia,

\section{THREE AGE OF WOMEN'S CONCEPTS DIFFERENCES: A STUDY OF THE DECONSTRUCTION OF JACQUES DERRIDA}

\begin{abstract}
Novels as representations of real life carry many themes that have been developing in society. One of the interesting and widely discussed themes is themes related to women. Each writer has their own way of keeping readers interested in the story being presented. This was done not only by presenting a different storyline, but also by carrying out different constructions on the female figure so that each story depicts a different image of a woman. This study aims to identify differences in the concept of women and to explain the elements of aporia in the novels of Siti Nurbaya, Belenggu, and Di Balik Kerling Saatirah. The approach used in this research is the deconstruction approach. This type of research is qualitative research. The research data are in the form of dialogue quotations, monologues, and narratives that are in accordance with the focus and objectives of the
\end{abstract}


research. The results of this study indicate that there are differences in the form of deconstruction of the concept of women as illustrated by the characterizations of Siti Nurbaya, Rohayah, and Saatirah. In addition, through deconstructive reading, elements of aporia can be found in the form of paradox, irony, and contradiction in the three novels.

Keywords: differentiation, women, deconstruction, aporia

\section{PENDAHULUAN}

Novel merupakan karya sastra yang menggambarkan tentang suatu peristiwa yang dialami tokoh-tokoh secara detail, pada umumnya bersifat fiktif dan berasal dari imajinasi penulis. Meskipun novel umumnya bersifat fiktif, kondisi-kondisi kehidupan sekitar penulis merupakan salah satu unsur penting yang memengaruhi penciptaan sebuah novel. Hal tersebut sesuai dengan pendapat Hendrawansyah (2018:25) bahwa novel merupakan karya fiksi yang menawarkan sebuah dunia imajiner dan fantastis. Oleh karena itu, kekuatan bahasa dalam novel sangat dibutuhkan dalam membangun jalan cerita dan menyampaikan pesan kepada pembaca. Bahasa yang digunakan dalam novel merupakan bahasa tingkat kedua. Menurut Barthes (dalam Kurniawan, 2001:115) bahasa tingkat kedua disebut juga metabahasa, yaitu bahasa yang memiliki banyak makna dan tidak dapat ditemukan makna ultima. Artinya, pencarian makna tunggal dalam novel merupakan suatu hal yang mustahil karena setiap kata, frasa, dan kalimat yang ada di dalam novel bermakna ganda dan tidak ada makna yang mutlak.

Novel yang merupakan representasi dari kehidupan nyata banyak mengangkat tema-tema yang selama ini berkembang di masyarakat. Salah satu tema yang menarik dan banyak diangkat adalah tema yang berhubungan dengan perempuan. Novel yang mengangkat tema kehidupan perempuan telah banyak diangkat oleh penulis-penulis Indonesia sejak masa penjajahan hingga sekarang. Meskipun tema perempuan telah banyak diangkat, namun setiap penulis selalu mempunyai cara tersendiri untuk membuat pembaca tetap tertarik dengan kisah yang disajikan. Hal itu dilakukan tidak hanya dengan penyajian jalan cerita yang berbeda, namun juga melakukan konstruksi yang berbeda-beda pada sosok perempuan sehingga setiap cerita menggambarkan citra perempuan yang berbeda pula. Perbedaan pandangan terhadap suatu hal tersebut pada umumnya terdapat dalam pengkajian dekonstruksi yang diprakarsai oleh Jacquest Derrida.

Jacques Derrida adalah seorang Yahudi Aljazair, ia lahir di Aljazair pada tahu 1930 kemudian pindah ke Prancis pada tahun 1959 dan mulai menarik perhatian publik pada akhir tahun 1965 , saat ia menerbitkan dua artikel panjang yang mengulas buku-buku tentang sejarah dan bentuk penulisan pada sebuah jurnal Paris, Critique, (Lechte, 2001:170). Latar belakang pemikiran Derrida sangat dipengaruhi oleh filsuf 
Edmund Husserl dan ahli bahasa Ferdinand de Saussure. Buku pertama Derrida adalah menerjemahkan karya Husserl yang berjudul The Origin of Geometry.

Di dalam bukunya yang berjudul of Grammatology, Derrida menyampaikan pandangannya terhadap pemikiran Saussure mengenai definisi bahasa. Ia mengatakanbahwa Saussure memberikan esensi manusia kepada bahasa. Logosentrisme dan fonosentrisme adalah paham yang berusaha dikritik Derrida. Menurutnya, kelemahan logosentrisme adalah menghapus dimensi material bahasa, dan kelemahan fonosentrisme adalah menomorduakan tulisan karena memprioritaskan ucapan, (Sugiharto, 1996:31).

Tulisan-tulisan Derrida sebagian besar berisi tentang pembacaan ulang suatu teks yang berpengaruh di dalam sejarah filsafat. Dalam tulisannya, Derrida tidak hanya menerjemahkan suatu teks berdasarkan apa yang telah ditulis oleh pengarang, namun ia memberikan makna-makna baru dan mengubah konsep yang telah digambarkan oleh pengarang. Derrida adalah seorang pembaca yang sangat cermat. Ia sangat sabar meneliti teks-teks yang ia baca. Beberapa teks yang pernah dimaknainya kembali adalah tulisan Plato yang berjudul Phaedrus, tulisah Shakespeare yang berjudul Romeo and Juliet, tulisan Kafka yang berjudul Before the Law, dan bahkan American Declaration of Independence, (Royle, 2003:21).

Hasil pemikiran dan kritik yang dilakukan oleh Derrida kepada rasionalisme Barat dan Husserl melahirkan teori dekonstruksi.
Dekonstruksi secara garis besar adalah cara untuk memahami kontradiksikontradiksi yang terdapat di dalam suatu teks dan mencoba untuk mengubah makna-makna yang telah melekat dalam teks tersebut. Dekonstruksi menolak memahami suatu teks secara konstan dan sesuai dengan yang tertera di dalam teks tersebut. Dekonstruksi menyakini bahwa suatu teks pasti memiliki faktafakta dan makna-makna yang tersembunyi dan berbeda dengan yang telah termaktub dalam teks tersebut. Andira (2016:3) mengatakan bahwa kebenaran absolut didapatkan melalui proses pemaknaan secara struktural, suatu makna tunggal yang umumnya disepakati para pembaca karya sastra yang menjadi objek.

Aliran dekonsruksi lahir di Prancis sekitar tahun 1960-an, kemudian berpengaruh besar di Amerika sekitar tahun 1970-an hingga pada tahun 1980an. Pada dasarnya, menurut Sarup (2011:51) dekonstruksi bertujuan untuk membongkar tradisi metafisika barat seperti fenomenologi Husserlian, strukturalisme Saussurean, strukturalisme Prancis pada umumnya, psikoanalisis Freudian, dan Psikoanalisis Lacanian. Tugas dekonstruksi mengungkap hakikat problematika wacana-wacana yang dipusatkan, di pihak yang lain membongkar metafisika dengan megubah batas-batasnya secara konseptual. Arisandy (2018:5) mengatakan bahwa dekonstruksi bermaksud untuk melacak teks yang tidak diunggulkan, yaitu berupa makna paradoksial, makna kontradiktif, makna ironi, 
Derrida menjelaskan dekonstruksi dengan kalimat negasi. Menurutnya, dekonstruksi bukan suatu analisis dan bukan kritik, bukan suatu metode, bukan aksi maupun operasi. Singkatnya, dekonstruksi bukanlah suatu alat penyelesaian dari suatu subjek individual atau kolektif yang berinisiatif dan menerapkannya pada suatu objek, teks, atau tema tertentu. Dekonstruksi adalah suatu peristiwa yang tidak menunggu pertimbangan, kesadaran, atau organisasi dari suatu subjek, atau bahkan modernitas, (Al-Fayyadl, 2012:8).

Kristeva (1980:36-37) menjelaskan bahwa dekonstruksi merupakan gabungan antara hakikat destruktif dan konstruktif. Dekonstruksi adalah cara membaca teks, sebagai strategi. Dekonstruksi tidak semata-mata ditunjukkan terhadap tulisan, tetapi semua pernyataan kultural sebab keseluruhannya pernyataan tersebut adalah teks yang dengan sendirinya sudah mengandung nilai-nilai, prasyarat, ideologi, kebenaran, dan tujuan-tujuan tertentu. Dekonstruksi dengan demikian tidak terbatas hanya melibatkan diri dalam kajian wacana, baik lisan maupun tulisan, melainkan juga kekuatankekuatan lain yang secara efektif mentransformasikan hakikat wacana.

Dekonstruksi memberikan dorongan untuk menemukan segala sesuatu yang selama ini tidak memperoleh perhatian. Memungkinkan untuk melakukan penjelajahan intelektual dengan apa saja, tanpa terikat dengan satu aturan yang dianggap telah berlaku universal. Setelah teks dibaca dengan pendalaman yang utuh, langkah selanjutnya dalam dekonstruksi adalah pembalikan dan penggantian. Hal tersebut sesuai dengan pendapat Sarup (2011:74) bahwa prinsip dekonstruksi adalah upaya untuk menemukan teks marginal yang menjanjikan, menyingkap, membongkar momen yang tidak dapat dipastikan dengan alat penanda yang pasif, membalikkan hierarki yang ada agar dapat diganti, membongkar agar dapat membangun kembali apa yang selalu telah tertulis.

Dekonstruksi merupakan jalan baru dalam membedah karya yang dapat digunakan dalam menemukan faktafakta yang tersembunyi dalam suatu bangunan teks. Oleh karena itu, dekonstruksi selalu diawali dengan sesuatu yang tidak pernah dipikirkan sebelumnya atau sesuatu yang dianggap tidak penting. Arisandy (2013:4) mengatakan bahwa teks dibangun dari pengandaian-pengandaian logis bahwa $\mathrm{x}$ merupakan penyebab dari y dan y merupakan akibat dari $\mathrm{x}$, dan hubungan antara keduanya merupakan hubungan logis yang tidak terelakkan. Oleh karena itu, dekonstruksi menolak pandangan bahwa bahasa memiliki makna yang pasti, sebagaimana yang disodorkan oleh strukturalisme. Bagi dekonstruksi bahasa merupakan sesuatu yang luas dan tidak terbatas.

Dekonstruksi memungkinkan setiap pembaca karya sastra menemukan makna yang tersembunyi dalam suatu karya sehingga setiap pembaca memiliki penafsiran yang berbeda, oleh sebab itu tidak ada makna tunggal yang dapat ditemukan dalam sebuah karya sastra. Hal tersebut sesuai dengan pendapat Rohman (2014:49) bahwa dekonstruksi memiliki metode kritis terhadap struktur, 
penolakan kebenaran final, pembaruan terhadap konsep bahasa, penolakan terhadap oposisi biner, dan kemampuan untuk menyusun konsep baru.

Bentuk pendekonstruksian sosok perempuan yang menurut budaya patriarki dianggap sebagai sosok lemah dan selalu tunduk di bawah laki-laki dapat ditemukan dalam karya sastra populer Indonesia yang berjudul Siti Nurbya: Kasih tak Sampai (1922) karya Marah Rusli. Di sisi lain, sosok perempuan yang lebih modern dan kuat dapat ditemukan dalam novel Belenggu (1940) karya Armijn Pane. Di samping itu, sosok perempuan dengan jiwa yang lebih berani, bebas, dan mandiri dapat ditemukan dalam novel Di Balik Kerling Saatirah (DBKS) karya Ninik M. Kuntarto (2010). Kontradiksi yang ditampilkan ketiga sosok perempuan dalam ketiga novel tersebut merupakan hal yang menarik untuk dikaji dan ditelusuri lebih dalam.

Melalui tokoh Siti Nurbaya dalam novel Sitti Nurbaya: Kasih tak Sampai, perempuan dicitrakan sebagai sosok yang lemah dan tidak berdaya dalam melawan kekuasan laki-laki. Perempuan hanya bisa pasrah dalam menghadapi perilaku laki-laki. Selain itu, perempuan dianggap sebagai manusia yang rendah dan memiliki kedudukan jauh di bawah lakilaki. Meskipun Siti Nurbaya tidak dapat memperbaiki hidupnya yang berantakan, namun di sisi lain banyak pertanyaan yang tersimpan dalam pemikirannya. Pemikiran-pemikiran yang tidak seharusnya dipikirkan oleh perempuan pada masa itu.

Hal berbeda dapat ditemukan pada sosok Rohayah dalam novel Belenggu.
Rohayah dicitrakan sebagai perempuan yang lebih kuat daripada sosok Siti Nurbaya, hal ini tergambar dari keberanian Rohayah dalam memutuskan jalan hidup yang ia pilih. Meskipun demikian, Rohayah tetap perempuan biasa yang tidak bisa lepas dari kodratnya sebagai sosok perempuan sejati yang memiliki kelembutan jiwa dan hati yang mudah goyah. Oleh karena itu, banyak keputusan-keputusan hidup yang ia ambil dengan hati gamang.

Di samping itu, dalam novel lain, yaitu novel $D B K S$ dapat ditemukan penggambaran sosok perempuan yang lebih modern, berpikiran bebas, dan memiliki keberanian untuk menunjukkan kelebihan dirinya digambarkan melalui sosok Saatirah. Jiwa kebebasan yang dimiliki oleh Saatirah membuatnya menjadi sosok perempuan yang berbeda sehingga berani untuk berselingkuh di belakang sang suami, suatu perbuatan yang sangatlah tabu dilakukan oleh perempuan. Namun, di balik segala keburukan Saatirah, dia juga merupakan seorang istri yang selalu melayani suaminya dengan sepenuh hati.

Melalui kontradiksi-kontradiksi yang ditemukan dalam ketiga novel tersebut, pembaca dapat menemukan sosok perempuan dengan konstruksi berbeda. Pemikiran-pemikiran yang bersarang dalam pikiran Siti Nurbaya meskipun tidak dapat diwujudkan dengan tindakan, namun secara tidak langsung melahirkan dikotomi mengenai citra perempuan. Begitu pula dengan sikap Rohayah dan Saatirah yang menyimpang dari citra umum yang melekat pada perempuan secara langsung mengonstruksi konsep perempuan. 
Pengkajian ketiga sosok perempuan tersebut lebih dalam dikaji secara dekonstruksi, yaitu sebuah alat bedah yang dapat digunakan untuk memahami sisi-sisi kontradiktif dari ketiga tokoh perempuan dalam novel. Melalui kajian dekonstruksi, jejak-jejak yang selama ini diabaikan di dalam sebuah teks dapat ditelusuri. Hal-hal yang dianggap tidak penting dan bukan bagian yang diutamakan dapat digunakan sebagai alat pembongkar konstruksi yang sebelumnya diutamakan dalam teks tersebut. Hal tersebut sesuai dengan pendapat Fatmawati (2017:32) dekonstruksi berusaha mengekspos ruang-ruang kosong dalam teks, asumsi yang tidak diketahui dan menjadi landasan kerjanya. Hal senada diungkapkan pula oleh Hidayat (2009:217) dekonstruksi bermaksud untuk melenyapkan dan menghilangkan kemapanan atau pemikiran yang sudah ada.

Berdasarkan uraian tersebut maka penulis tertarik untuk melakukan penelitian dengan judul Diferensiasi Konsep Perempuan Tiga Zaman: Kajian Dekonstruksi Derrida. Penelitian ini bertujuan mengidentifikasi perbedaan konsep perempuan dalam novel Sitti Nurbaya, Belenggu, dan Di Balik Kerling Saatirah dan memaparkan unsur aporia dalam Novel Sitti Nurbaya, Belenggu, dan Di Balik Kerling Saatirah.

Adapun penelitian tentang kajian Dekonstruksi Derrida dalam suatu karya sastra adalah sebagai berikut. Pertama, penelitian dalam puisi Nemor karya Penyair Madura. Penelitian tersebut dilakukan oleh Kusumawati (2016) yang berusaha untuk mendekonstruksi konsep cantik yang selama ini dipercayai oleh perempuan Madura. Kedua, penelitian terhadap novel Laskar Mawar karya Barbara Victor yang dilakukan oleh Afdholy (2019). Dalam penelitian ini, Afdholy berusaha membongkar dan mengamati makna jihad yang dilakukan oleh tokoh-tokoh dalam novel sehingga menimbulkan pemaknaan baru pada istilah kata jihad.

\section{METODE}

Dalam penelitian ini, pendekatan yang digunakan, yaitu pendekatan dekonstruksi. Penelitian dengan pendekatan dekonstruksi merupakan salah satu cara yang digunakan dalam ilmu sastra untuk menemukan maknamakna lain yang tersembunyi dalam sebuah teks. Hal tersebut sesuai dengan pendapat Rohman (2014:35) yang menyatakan bahwa pendekatan dekonstruksi adalah sebuah model berpikir kritis terhadap strukturalisme. Pendekatan dekonstruksi menolak adanya gagasan makna pusat karena dekonstruksi menganggap bahwa sebuah teks itu multitafsir.

Jenis penelitian ini adalah penelitian kualitatif, yaitu penelitian yang menggambarkan tingkah laku individu, gejala, keadaan, atau kelompok tertentu. Sesuai dengan permasalahan yang diteliti, penelitian ini berupaya mengidentifikasi perbedaan konsep perempuan dalam novel Sitti Nurbaya, Belenggu, dan Di Balik Kerling Saatirah, serta memaparkan unsur aporia yang ada di dalam Novel Sitti Nurbaya, Belenggu, dan Di Balik Kerling Saatirah terurai dalam bentuk kata-kata dan bukan dalam bentuk angka-angka. 
Sumber data penelitian ini, yaitu Novel Sitti Nurbaya karya Marah Rusli yang diterbitkan oleh PT Balai Pustaka pada tahun 1922, novel Belenggu karya Armijn Pane yang diterbitkan oleh Dian Rakyat pada tahun 1940, dan novel $D i$ Balik Kerling Saatirah karya Ninik M. Kuntarto yang diterbitkan oleh PT Gramedia Pustaka Utama pada tahun 2010. Pada penelitian kualitatif, peneliti merupakan instrumen utama. Posisi peneliti dalam penelitian kualitatif sebagai human instrument berfungsi menetapkan fokus penelitian, melakukan pengumpulan data, menilai kualitas data, analisis data, menafsirkan data, dan membuat simpulan atas temuannya.

Data penelitian ini merupakan kutipan-kutipan dialog, monolog, dan narasi yang sesuai dengan tujuan penelitian. Teknik pengumpulan data dilakukan dengan membaca kritis secara berulang, kemudian mengidentifikasi dengan cara mengkode dan menyeleksi data. Analisis data dilakukan dengan cara (1) kodifikasi teks, mendeskripsikan makna teks, (3) mendeskripsikan wujud dekonstruksi dalam teks, dan (4) menyimpulkan hasil analisis.

\section{HASIL DAN PEMBAHASAN \\ Hasil}

\section{Bentuk Dekonstruksi Konsep Perempuan}

Berdasarkan hasil analisis data pada novel Sitti Nurbaya: Kasih tak Sampai melalui sosok Siti Nurbaya, novel Belenggu melalui sosok Rohayah, dan dalam novel $D B K S$ melalui sosok Saatirah ditemukan dekonstruksi konsep perempuan yang berbeda. Bentuk dekonstruksi konsep perempuan yang pertama pada novel Sitti Nurbaya: Kasih tak Sampai didasarkan pada pemikiran Siti Nurbaya yang menganggap bahwa perempuan harusnya menolak perjodohan jika perjodohan itu tidak sesuai dengan keinginan hatinya. Perempuanseharusnya tidakterkungkung oleh aturan perjodohan, sebagaimana terlihat pada Kutipan 01 berikut.

\section{Kutipan 01 \\ "Bila engkau kelak beranak perempuan, janganlah sekali-kali kau paksa kawin dengan laki-laki yang tiada disukainya. Karena telah kurasai sendiri sekarang ini, bagaimana sakitnya, susahnya dan tak enaknya, duduk dengan suami yang tiada disukai. (D.172:SN)}

Kutipan 01 tersebut menunjukkan pemikiran Siti Nurbaya yang menganggap bahwa perempuan harusnya diberi hak untuk memilih pria yang akan dinikahinya karena dialah yang akan menjalani kehidupan rumah tangga.

Dekonstruksi konsep perempuan yang kedua tercermin dari keberanian Siti Nurbaya dalam mencaci dan memaki suaminya. Siti Nurbaya, berulang kali mencerca dan menghina Datuk Maringgih. Dia tidak pernah menunjukkan rasa bakti dan hormatnya pada sang suami.

\section{Kutipan 02}

Aku pun kau seret pula ke dalam kekejian, untuk memuaskan hawa nafsumu, yang terlebih hina pada hawa nafsu hewan. Sekarang ayahku telah mati; barulah senang hatimu, bukan? Akan tetapi pada waktu inilah pula, 
aku terlepas dari tanganmu, hai bangsat! Aku dahulu menurut kehendakmu, karena hendak membela ayahku, supaya jangan sampai engkau penjarakan dia. Sekarang ayahku tak ada lagi, putus pula sekalian tali yang mengikatkan aku kepadamu. Janganlah engkau harap, aku akan kembali kepadamu. Manusia yang sebagai engkau, tiada layak bagiku. Rupamu sebagai hantu pemburu, tuamu sama dengan nenekku, tabiatmu terlebih jahat dari tabiat binatang yang buas. Apa yang dapat kupandang padamu? Uangmu yang engkau peroleh dengan tipu daya, darah keringat mereka yang telah engkau aniaya itu? Apa gunanya uang itu bagiku? Karena kikirmu, engkau sendiri pun tak dapat memakai uang itu. Siapa tahu barangkali hartamu itu kau peroleh dengan jalan mencuri dan menyamun. Seram badanku, jika kuingat akan hal itu." (D.183:SN)

Kutipan 02 tersebut menunjukkan keberanian Siti Nurbaya dalam mengutarakan pemikirannya bahwa Datuk Maringgih bukanlah pria yang pantas untuk dirinya, selain memiliki wajah yang buruk, perangainya pun buruk pula.

Dekonstruksi konsep perempuan yang ketiga menggambarkan sosok Siti Nurbaya yang menolak adanya pernikahan usia dini, meskipun Siti Nurbaya saat itu merupakan salah satu korban dari pernikahan di usi muda. Menurut Siti Nurbaya pernikahan di usia muda dapat menyebabkan berbagai masalah kehidupan, mulai dari kesehatan perempuan yang melahirkan di usia muda, kesehatan anak yang dilahirkan, cara pengasuhan terhadap anak-anak, dan lain sebagainya.

\section{Kutipan 03}

Oleh sebab itu tak boleh aku kawin terlalu muda, tak baik bagi badanku dan tak baik pula lagi turunanku. Tentu saja, masakan biji yang belum sempurna tua, jika ditanam, dapat tumbuh menjadi pohon yang besar dan baik, yang menghasilkan buah yang banyak dan besar-besar? Tentu tidak. Tetapi, kebanyakan ibu-bapa di Padang ini tiada mengingat hal itu. Asal untungnya lepas, katanya senanglah hatinya, dengan tidak memikirkan anak cucu dan turunannya di kemudian hari. (M.111:SN)

Kutipan 03 tersebut menunjukkan pemikiran Siti Nurbaya yang menentang adanya pernikahan usia muda yang tentu saja bertentangan dengan keadaan sebagian besar masyarakat Indonesia pada saat itu karena sebagian besar masyarakat masih sangat terkungkung dengan budaya patriarki.

Bentuk dekonstruksi konsep perempuan yang keempat tercermin dari pola pikir Siti Nurbaya yang menganggap bahwa pendidikan merupakan hal yang penting untuk perempuan agar tidak diremehkan kaum laki-laki. Bagi Nurbaya yang berhak menerima pendidikan tinggi bukan hanya kaum laki-laki, namun juga kaum perempuan.

\section{Kutipan 04 \\ "Biarlah perempuan menuntut ilmu yang berguna baginya, biarlah ia diizinkan melihat dan mendengar}


segala ,yang boleh menambah pengetahuannya; biarlah ia boleh mengeluarkan perasaan hatinya dan buah pikirannya, supaya dapat bertukar-tukar pikiran, untuk menajamkan otaknya. Dan berilah ia kuasa atas segala yang harus dikuasainya, agar jangan sama ia dengan boneka yang bernyawa saja." (D.252:SN)

Kutipan 04 tersebut menunjukkan betapa Siti Nurbaya sangat berharap perempuan dapat memperoleh pendidikan yang tinggi.

Jika Nurbaya hanya berhenti pada pemikiran tanpa dapat mewujudkannya dalam sebuah tindakan, Rohayah dalam novel Belenggu menciptakan gambaran yang berbeda mengenai sosok perempuan. Melalui perilaku dan tindakannya, citra perempuan dibongkar dan direkonstruksi. Rohayah memiliki keberanian yang lebih besar daripada Siti Nurbaya. Hal itu terbukti dari tindakan yang dilakukan oleh Rohayah. Jika Nurbaya hanya berani untuk berpikir tanpa bertindak, Rohayahlah yang mewujudkannya dalam tindakan.

Perempuan pada umumnya dikenal sebagai sosok pemalu dan hanya menunggu jodoh, tanpa dapat memilih jodohnya. Namun, Rohayah melakukan hal berbeda. Bentuk dekonstruksi konsep perempuan dalam diri Rohayah yang pertama tercermin melalui keberaniannya dalam menunjukkan rasa tertarik pada laki-laki.

\section{Kutipan 05 \\ "Sampai terdengar olehku, engkau di Betawi sini menjadi}

dokter...Terbit ingin hatiku bersua dengan engkau dengan zaman dahulu, zaman aku masih gadis, masih putih bersih...untuk bersua sekejap saja. Aku pura-pura sakit. Ketika engkau memeriksa aku, terbit nafsuku sedia kala hendak mencoba engkau, hendak merasa menang, hendakkan engkau takluk, tunduk sebagai laki-laki lain juga. Engkau menahan, aku merasa kesal akan perbuatanku hendak mencoba mengotorkan ingatanku..."(D.51:B)

Pada Kutipan 05 tersebut Rohayah secara terang-terangan dan tanpa segan berusaha untuk mencari perhatian dari pria yang disukainya. Hal tersebut bukanlah suatu hal yang biasa dilakukan oleh perempuan. Pada umumnya, lakilakilahyang pertamakalimengungkapkan perasaannya kepada perempuan bukan sebaliknya. Oleh karena itu, selama ini di sebagian besar lingkungan masyarakat laki-lakilah yang datang ke rumah perempuan untuk melamar, bukan sebaliknya.

Bentuk dekonstruksi konsep perempuan dalam diri Rohayah yang kedua tercermin melalui tindakannya ketika meninggalkan sang suami. Pada umumnya saat telah berumah tangga, perempuan haruslah mengikuti ke mana pun suaminya pergi dan tidak seharusnya pergi tanpa pamit kepada suami.

\section{Kutipan 06}

"Hatiku tiada tahan. Cuma tiga tahun saja. Aku pun mengembara lagi. Tono, aku benar jahat. Di dalam hatiku tertawa sebagian setan tertawa, kalau ada laki-laki terpikat olehku. Kalau dia 
merendahkan diri tidur dengan aku, aku senang, aku gembira karena dia tertarik ke lumpur tempat aku hidup." (D.51:B)

Kutipan 06 tersebut menunjukkan keberanian seorang Rohayah dalam meninggalkan sang suami yang tidak dicintainya demi mencari cinta sejatinya. Rohayah tanpa rasa takut terus mencari keberadaan sang cinta sejati tanpa peduli dengan suaminya atau tuannya. Rohayah dengan berani mengejar laki-laki yang dicintainya sedangkan Nurbaya hanya bisa menyimpan cinta sejatinya dalam pikirannya.

Bentuk ketiga dari dekonstruksi konsep perempuan yang tercermin dalam diri Rohayah dapat terlihat dari sosok Rohayah yang memiliki pengetahuan luas. Padahal pada masa itu perempuan masih dianggap sebagai kaum tidak yang lemah pengetahuan.

\section{Kutipan 07 \\ “...Tuanku banyak bukunya, dia suka membaca. Aku coba juga membaca, karena kulihat dia tenang kalau membaca. Mulanya tiada lut, kemudian lambat laun hati jiwaku terpendam oleh bacaan. Buku apa saja kubaca. "Dia tersenyum: "Karena itulah banyak pikiran dalam kepalaku, yang tiada berketentuan, yang tiada patut disimpan dalam kepala perempuan." (D.50:B)}

Kutipan 07 tersebut menunjukkan bahwa Rohayah sangatlah berbeda dengan perempuan-perempuan lain pada masa itu. Ia memiliki pengetahuan luas dan pemikiran-pemikiran yang dalam.
Selain sosok Siti Nurbaya dan Rohayah ada pula sosok Saatirah, sosok perempuan yang lebih modern dengan pemikiran-pemikiran terbuka, kepribadian yang bebas, perilaku yang menyimpang, dan mandiri dapat ditemukan pada novel DBKS. Kepribadian dan perilaku yang ditunjukkan oleh Saatirah membongkar citra perempuan pada umumnya hingga ke akarnya. Melalui sosok Saatirah, perempuan benar-benar direkonstruksi ulang seperti sebuah bangunan yang dihancurkan hingga ke fondasinya untuk kembali dibangun dengan bangunan berarsitektur baru.

Melalui sosok Saatirah dalam novel $D B K S$ dapat ditemukan sebuah rekonstruksi perempuan dengan pemikiran-pemikiran modern, perilaku yang lebih bebas dalam berekspresi dan bertindak, dan kepribadian yang kuat. Dekonstruksi konsep perempuan dalam diri Saatirah yang pertama tercermin dari sikap Saatirah yang merupakan perempuan bersuami, namun mengharapkan perhatian dan kasih sayang dari pria lain.

\section{Kutipan 08}

Perhatian demi perhatian diberikan Tora padaku. Hadiah-hadiah kecil dari daerah tempat ia meliputnya, selalu diberikan padaku. Sampai suatu hari, tak ada kabar berita darinya. SMS atau telepon dari dia tak menyapaku lagi. Ke manakah? Di manakah? SMS kukirimkan. Selalu gagal. Handphone nya kuhubungi, tak pernah berhasil. Mengapa aku merasa kehilangan dia? (N.33:DBKS) 
Kutipan 08 tersebut menunjukkan perilaku Saatirah sebagai seorang perempuanbersuamiyang mengharapkan perhatian dan kasih sayang dari pria lain bahkansaatpriaitutidakmenghubunginya ada rasa rindu yang dirasakannya. Hal itu merupakan hal yang tidak sepantasnya terjadi. Perilaku yang demikian mencederai citra perempuan sebagai sosok yang setia. Dalam masyarakat, seorang perempuan yang telah bersuami mengharapkan kasih sayang dan perhatian dari pria lain diangggap sebagai suatu hal yang tidak pantas dan tidak wajar. Meskipun ada, perempuan tersebut akan diberikan label sebagai perempuan murahan. Hal itu akan berbeda apabila seorang suami yang melakukannya karena jarang sekali dalam masyarakat menggunakan pelabelan pada pria dengan menyebut "pria murahan".

Pengharapan Saatirah untuk mendapatkan perhatian dan kasih sayang dari pria lain meruntuhkan pandangan patriarki bahwa perempuan haruslah tunduk kepada suaminya dan menjaga martabat sang suami serta mengabdikan hidupnya untuk memberikan kebahagian kepada sang suami.

Selain mengharapkan perhatian dan kasih sayang dari pria lain, bentuk dekonstruksi konsep perempuan pada sosok Saatirah yang kedua tercermin dari penghianatannya kepada sang suami. Ia melakukan hubungan terlarang dengan pria lain di belakang suaminya.

\section{Kutipan 09}

Ia duduk di sampingku. Terkejut. Serempak aliran darah deras mengalir ke seluruh tubuhku. Kami saling pandang. Tak ada kata terucap. Waktu terhenti. Jantungku berdetak lagi. Yang sebelumnya mati. Jiwaku kembali utuh. Yang sebelumnya tinggal setengah dan membeku. Kini, waktu terhenti dan aku bangkit dari kematian. Tak sadarkan diri ketika bibir mulai merapat. Ketika embusan napas terasa hangat. Sangat dekat. Kutemukan tatapan itu. tatapan cinta mendalam. Saat bibir mulai mengecup. Mata setengah mengatup. Dua jiwa menyatu. Tak sadarkan diri, hanyut jiwaku di antara gerimis yang berhamburan membentur-bentur kaca mobil. Di antara kuluman bibir dan kehangatan tubuhnya. Ingin ku berteriak. Oh Tora, dirimu adalah stupa. Yang bertapa di jiwaku. Aroma tubuhmu adalah wangi bunga yang mengharum di relung hatiku. (N.36:DBKS)

Kutipan 09 tersebut menunjukkan pengkhianatan Saatirah kepada suaminya dengan melakukan perbuatan sensual bersama pria lain. Pada umumnya seorang perempuan bersuami akan menjaga kehormatannya dan hanya akan menyerahkan tubuhnya kepada sang suami bukan kepada pria lain. Dalam hal ini Saatirah terlihat lebih berani dan lebih percaya diri daripada Rohayah karena Saatirah saat menjalin hubungan dengan pria pujaannya masih bersuami sedangkan Rohayah yang mengharapkan cinta Tono saat itu sedang sendiri. Perilaku yang ditunjukkan oleh Saatirah tersebut secara tidak langsung menggiring opini bahwa ia ingin mendapatkan perlakuan yang sama seperti laki-laki, yaitu apabila laki-laki bisa memiliki dua atau bahkan lebih cinta maka perempuan 
pun dapat pula melakukan hal yang sama.

Selain perselingkuhan yang dilakukan oleh seorang istri dianggap tidak biasa terjadi, istri yang menjadi tulang punggung keluarga juga dianggap sebagai suatu hal yang tidak umum. Dalam hal ini dekonstruksi konsep perempuan yang ketiga dalam novel $D B K S$ ditunjukkan oleh Saatirah melalui perannya sebagai tulang punggung keluarga.

\section{Kutipan 10}

Hari-hariku penuh dengan tagihan kartu kredit. Sudah biasa ku hadapi dept collector yang datang ke rumah sambil marah-marah penuh ancaman. Bahkan, berteriak-teriak di pintu gerbang ketika ia tahu bahwa aku menghindar dan bersembunyi. Bersyukurlah aku bekerja, sedikit demi sedikit roda perekonomian keluarga dapat dipertahankan. (N.129:DBKS)

Kutipan 10 tersebut menunjukkan kerja keras Saatirah dalam menanggung beban perekonomian keluarganya yang sedang berantakan. Sebagai seorang yang bekerja, Saatirah pun mampu menjelma menjadi perempuan mandiri yang dapat mencukupi semua kebutuhan hidupnya tanpa bantuan orang lain. Dekonstruksi konsep perempuan keempat yang ditemukan dalam diri Saatirah tercermin dari kemandiriannya secara finansial.

\section{Kutipan 11}

Aku berusaha bangkit mengais kekuatan talentaku sebagai model. Aku pun bisa menjadi model kembali. Kali ini sebagai model iklan di berbagai media massa, aku bisa menjadi narasumber di beberapa seminar, dan dengan cepat aku berhasil menempati posisi direktur untuk sebuah bagian di kampus tempatku mengajar. Terakhir, secara mengejutkan aku dilamar sebagai bakal calon wakil bupati Majalengka. (N.135:DBKS)

Melalui Kutipan 11 tersebut diketahui sosok Saatirah yang memiliki pekerjaan sebagai seorang dosen, pembicara dalam seminar, model, dan juga penulis dapat dicerminkan sebagai sosok perempuan yang mandiri bahkan tanpa mendapatkan tunjangan dari sang suami Saatirah tetap dapat bertahan hidup dengan berkecukupan.

\section{Unsur Aporia: Paradoks, Ironi, dan Kontradiksi}

Selain perbedaan dekonstruksi konsep perempuan, di dalam ketiga novel tersebut ditemukan pula unsur-unsur aporia berupa paradoks, ironi, dan kontradiksi. Unsur aporia pertama yang terdapat di dalam Novel Sitti Nurbaya: Kasih tak Sampai adalah paradoks yang tercermin dari sikap Siti Nurbaya yang sama sekali tidak mau menunjukkan rasa hormat pada suaminya.

Kutipan 12

Bagaimanakah dapat kusabarkan hatiku, bagaimanakah dapat kusenangkan pikiranku, dan bagaimana pula dapat aku hidup manis dengan orang yang sedemikian? Makin hari, makin kusut pikiranku, makin bertambah dukacita dan sedih hatiku, dan makin bertambah-tambah pula benci hatiku melihat rupanya. (D.171:SN) 
Kutipan 12 tersebut menunjukkan betapa tidak berharganya sosok sang suami di mata Siti Nurbaya. Ia sebagai seorang istri seharusnya dapat menghargai sang suami apa pun keadaan dan kondisinya, namun dalam pikiran Nurbaya sang suami bukanlah sosok yang patut untuk dihormati sehingga hanya pemikiran-pemikiran jelek saja tentang suaminya yang mengendap dalam pikiran Nurbaya.

Pada sosok Rohayah dalam novel Belenggu, paradoks pertama dapat ditemukan dari sikap Rohayah yang mempunyai pengetahuan dan wawasan luas. Menurut sebagian masyarakat saat itu perempuan berpengetahuan luas dan berpendidikan bukanlah hal yang baik karena dengan pengetahuan yang dimiliki oleh perempuan dapat menyebabkan seorang perempuan menentang suaminya.

\section{Kutipan 13}

Tuanku banyak bukunya, dia suka membaca. Aku coba juga membaca, karena kulihat dia tenang kalau membaca. Mulanya tiada lut, kemudian lambat laun hati jiwaku terpendam oleh bacaan. Buku apa saja kubaca. "Dia tersenyum: "Karena itulah banyak pikiran dalam kepalaku, yang tiada berketentuan, yang tiada patut disimpan dalam kepala perempuan. (D.50:B)

Kutipan 13 tersebut menunjukkan Rohayah yang begitu mencintai dunia membaca dan memperluas pengetahuan.

Paradoks kedua yang ditemukan dalam novel Belenggu tercermin dari tindakan Rohayah yang meninggalkan suaminya. Saat ia merasakan ketidakcocokan dengan pasangannya dengan berani Rohayah mencari tambatan hati lainnya.

\section{Kutipan 14}

"Hatiku tiada tahan. Cuma tiga tahun saja. Aku pun mengembara lagi. Tono, aku benar jahat. Didalam hatiku tertawa sebagian setan tertawa, kalau ada laki-laki terpikat olehku. Kalau dia merendahkan diri tidur dengan aku, aku senang, aku gembira karena dia tertarik ke lumpur tempat aku hidup." (D.51:B)

Kutipan 14 tersebut menggambarkan sosok Rohayah yang dengan berani mengambil keputusan untuk meninggalkan pasangannya demi mencari kebahagian dengan cinta sejatinya. Pada masa itu perempuan yang meninggalkan suaminya dipandang sebagai sosok perempuan yang tidak baik, tidak punya adab, dan terhina. Terlebih apabila perempuan tersebut mengejar-ngejar laki-laki lain yang sudah beristri, hinaan yang didapat tentulah lebih parah. Namun, Rohayah menampakkan hal yang berbeda, ia seorang perempuan yang memiliki tingkah laku terpelajar dan tertib, jauh dari perilaku yang selama ini ditunjukkan perempuan jalanan pada umumnya.

Paradoks ketiga dalam novel Belenggu tergambar dari sosok Rohayah yang selalu terlihat ceria. Ia tak pernah menampakkan penyesalan atas jalan hidup yang dilaluinya meski penuh gelombang. 
Kutipan 15

Melintas gambaran Rohayah di ruang mata Tono, Rohayah lemah lembut, riang gembira, walaupun sudah menderita kesedihan yang amat sangat; karena pengalamannya itu malahan perasaannya dalam, masak, ranum; dasarnya hendak girang-girang saja itu menarik hati...(N.60:B)

Kutipan 15 tersebut menunjukkan sosok Rohayah yang ceria meski telah melewati berbagai rintangan hidup dan penderitaan, ia tetap menampakkan ketegaran dan keteguhan hati. Perempuan yang selama ini dicitrakan berhati lembut, rapuh, dan tergambar sebagai sosok yang lemah dalam lingkungan masyarakat dapat ditentang oleh sosok Rohayah. Sosok Rohayah menampilkan citra perempuan yang berbeda dari yang saat itu diyakini oleh sebagian besar masyarakat.

Paradoks pertama dalam novel $D B K S$ terlihat dari sikap Saatirah yang merupakan perempuan bersuami, namun merasakan kerinduan mendalam pada pria lain dan merasa cemas jika pria itu tidak menghubunginya.

\section{Kutipan 16}

Tiga minggu kemudian, tiba-tiba Tora menghubungiku...

Senang, bahagia ku terima pesan itu. Lama ku nanti. Namun, pesan itu kubiarkan. Tak ku balas. Aku mulai takut. Ada sesuatu yang berubah dalam hatiku. Debaran yang tak menentu. Bila $\mathrm{ku}$ ingat wajahnya, sesuatu mengalir dengan cepat dari hulu hati naik ke otak dan turun secara bersamaan. Serempak. Menyebarkan getaran-getaran indah itu ke seluruh tubuh dan bermuara di laut itu. Kusadari bahwa aku merindukan dia. (N.33:DBKS)

Kutipan 16 tersebut menggambarkan sosok Saatirah yang menunggu dan berharap agar pria idaman barunya yang bernama Tora menghubungi dan memberikan kabar kepadanya. Hal ini tidak sesuai dengan kejadian atau situasi yang diyakini oleh lingkungan masyarakat karena seharusnya seorang istri haruslah dapat menjaga hatinya yang patut dirindukan dan dicemaskan adalah suaminya bukan pria lain. Selain itu, Saatirah juga berharap untuk mendapat kasih sayang dari Tora. Harusnya Saatirah sebagai seorang istri hanya menerima kasih sayang yang diberikan oleh suaminya.

Paradoks kedua dalam novel $D B K S$ tergambar melalui sosok Saatirah sebagai seorang istri yang bekerja keras membanting tulang untuk membayar hutang-hutang suaminya dan membiayai kehidupan keluarganya. Ia tak bisa mengandalkan suaminya yang saat itu tak lagi bekerja.

\section{Kutipan 17}

Hari-hariku penuh dengan tagihan kartu kredit. Sudah biasa ku hadapi dept collector yang datang ke rumah sambil marah-marah penuh ancaman. Bahkan, berteriak-teriak di pintu gerbang ketika ia tahu bahwa aku menghindar dan bersembunyi. Bersyukurlah aku bekerja, sedikit demi sedikit roda perekonomian keluarga dapat dipertahankan. (N.129:DBKS) 
Kutipan 17 tersebut menunjukkan usaha dan kerja keras Saatirah dalam menjalankan roda perekonomian keluarganya.

Unsur aporia kedua yang terdapat di dalam ketiga novel beda zaman adalah ironi. Ironi pada tiga novel tersebut terletak pada kondisi batin yang dialami Siti Nurbaya, situasi lingkungan masyarakat tempat Rohayah tinggal, dan perasaan yang dirasakan oleh Saatirah. Dalam Novel Sitti Nurbaya: Kasih tak Sampai, ironi dapat terlihat dari keinginan dan pemikiran Siti Nurbaya yang berharap agar perempuan dapat memiliki kehendak yang sama dengan laki-laki sehingga tidak lagi terjadi penindasan pada kaum perempuan yang dilakukan oleh kaum laki-laki.

\section{Kutipan 18 \\ "Demikian pula tentang sifat-sifat perempuan itu, bukan ia yang memintanya. Adalah patut laki-laki menghinakan dia, sebab kita beroleh sifat-sifat ini? Pada pikiranku, tentang kemauan dan akal itu, bila kita perempuan diberi pelajaran, pemeliharaan, makanan, pendeknya sekaliannya sama benar-benar dengan laki-laki, tentulah kita tak akan kalah dari laki-laki." (D.247:SN)}

Kutipan 18 tersebut menunjukkan pemikiran Siti Nurbaya untuk mendapatkan keadilan dalam perlakuan untuk perempuan. Siti Nurbaya berpikir dengan adanya kesamaan kehendak antara laki-laki dan perempuan, keduanya dapat saling melengkapi tanpa ada yang bertindak lebih dominan.
Jika Nurbaya hanya dapat memendam harapannya dalam hati dan tersimpan dalam pikirannya, hal berbeda dilakukan oleh Rohayah. Ia dengan berani menentang norma masyarakat yang memperlakukan perempuan sebagai pihak yang disetir bukan yang menyetir. Rohayah dengan keberaniannya memilih untuk meninggalkan suaminya tanpa pamit (melarikan diri).

\section{Kutipan 19 \\ "Ah, apa perlunya lagi kuterangkan panjang-panjang aku kemudian lari sampai ke Betawi, pulang ke Bandung, orangtuaku sudah tiada disana, aku tiada berumah tetap, rumahku di hotel berganti-ganti, pindah dari kota satu ke kota lain." (D.50:B)}

Kutipan 19 tersebut mendeskripsikan sosok Rohayah melarikan diri dari sang suami. Pandangan saat itu bahwa suami merupakan penentu kehidupan bagi istrinya dan yang berhak memutuskan segala arah hidup yang diambil istrinya dilawan oleh Rohayah dengan tindakannya melarikan diri dari sang suami. Perbuatan Rohayah tersebut sangatlah bertentangan dengan harapan yang ditanamkan oleh orangtuanya dan masyarakat sekitar tempat tinggal.

Orangtua Rohayah tentulah sangat berharap agar anak perempuannya itu dapat hidup damai dan bahagia dengan suaminya. Ironi juga dapat ditemukan melalui sosok Saatirah yang merasakan kerinduaan kepada pria lain bukan kepada suaminya. Saatirah menyadari bahwa hal tersebut tidak seharusnya terjadi, ia berharap yang dirindukannya 
adalah Andro bukan pria lain, namun kenyataannya Saatirah merindukan sang kekasih hati, yaitu Tora.

\section{Kutipan 20}

"Akhh...mengapa aku merasakan kerinduan pada lelaki lain, bukan pada Mas Andro." (M.33:DBKS)

Kutipan 20 tersebut menunjukkan kegundahan hati Saatirah ketika ia menyadari bahwa pria yang dirindukannya adalah Tora bukan Andro sang suami. Tentu saja perasaan tersebut tidak seharusnya dimiliki oleh seorang perempuan bersuami.

Unsur aporia ketiga yang terdapat di dalam ketiga novel tersebut adalah kontradiksi. Kontradiksi dalam ketiga novel terletak pada tindakan yang dilakukan oleh Nurbaya, Rohayah, dan Saatirah yang tidak sesuai atau bertentangan dengan pemikiran yang bersarang dalam pikiran kedua tokoh perempuan tersebut. Nurbaya merupakan sosok perempuan yang menikah karena dijodohkan oleh ayahnya. Menikah dengan cara perjodohan merupakan tindakan yang ditentang oleh Nurbaya.

Perjodohan adalah hal yang bertolak belakang atau kontradiktif dengan jalan pikiran Nurbaya. Selain menentang perjodohan, Nurbaya merupakan sosok perempuan yang menganggap bahwa pernikahan perempuan di usia muda bukanlah hal yang baik. Oleh karena itu, ia berharap agar masyarakat menghentikan tradisi pernikahan dini pada masa itu. Namun, pemikiran Nurbaya tersebut sayangnya tidak sejalan atau bertolak bertentangan dengan jalan hidup Nurbaya. Selain menjadi perempuan korban perjodohan, ia juga merupakan perempuan yang dinikahkan pada saat usia muda.

Hal serupa pun terjadi pada sosok Rohayah. Pada satu sisi Rohayah dicitrakan sebagai seorang perempuan yang tangguh, selalu berpikiran positif, dan tidak mudah panik saat mengambil keputusan, namun ternyata di sisi lain ia juga menyimpan kekhawatiran dalam hatinya. Bayang-bayang masa lalu yang penuh dengan lembaran kelam membuat hidup Rohayah tidak tenang. Hal itu pula yang menyebabkan Rohayah mengambil keputusan untuk meninggalkan Tono, laki-laki yang sangat dicintainya.

Perbuatan Rohayah yang meninggalkan Tono sangatlah bertolak belakang dengan keinginan hati Rohayah yang selalu ingin dekat dengan Tono dan mengharapkan cinta Tono seutuhnya. Perbuatan Rohayah yang bertolak belakang dengan keinginan hatinya dan perjuangannya selama ini untuk mendapatkan Tono merupakan akibat dari ketakutan Rohayah tentang masa lalunya yang kelam dapat membuat nama baik Tono tercemar dan dapat menyebabkan Tono mendapat cemoohan orang.

Kontradiksi dalam novel $D B K S$ tecermin melalui perilaku Saatirah yang mengkhianati sang suami, ia melakukan perselingkuhan dengan laki-laki yang lebih mudah daripada dirinya. Semua hal tersebut dilakukan tanpa sepengetahuan sang suami. Perselingkuhan yang dilakukan Saatirah bertolak belakang dengan usahanya yang selalu ingin terlihat menarik di depan sang suami agar sang suami tetap mencintainya. Perilaku Saatirah yang demikian dapat 
diindikasikan bahwa kemungkin ia menginginkan dua laki-laki dalam hidupnya. Satu sisi ia ingin sang suami mencintainya dengan sepenuh hati, namun di sisi lain ia juga tetap menjalin hubungan dengan laki-laki lain. Keadaan tersebut tentu sangatlah tidak sejalan dengan norma masyarakat yang melarang seorang perempuan memiliki dua lakilaki dalam kehidupannya.

Selain itu, kontradiksi juga terlihat dari kepribadian Saatirah. Saatirah yang memiliki kepribadian mandiri bertolak belakang tergambar melalui perilakunya yang tidak manja, selalu pergi kemanamana sendiri, mempunyai pekerjaan dengan penghasilan tetap, apabila ada masalah ia memendamnya sendiri dan berusaha menyelesaikan masalah tersebut dengan caranya sendiri.

\section{Pembahasan}

\section{Bentuk Dekonstruksi Konsep Perempuan}

Secara keseluruhan bentuk dekonstruksi konsep perempuan dan unsur aporia dalam ketiga novel dari era yang berbeda terangkum dalam Tabel 1 . Pada Tabel 1 terlihat bahwa pada ketiga novel: Sitti Nurbaya: Kasih tak Sampai, Belenggu, dan DBKS telah berlangsung upaya mendekonstruksi konsep perempuan yang selama ini melekat di masyarakat umum. Ini berarti bahwa upaya membaca suatu teks secara dekonstruksi-membaca teks dengan cara melacak makna-makna tersembunyi dalam teks yang digambarkan melalui ambiguitas tokoh-telah terwujud sebagaimana disarnkan oleh Setyawati (2020:3) dan Andira (2016:17) bahwa tahapan yang menjadi inti analisis dekonstruksi adalah menangguhkan kebenaran tunggal dengan memperhatikan dan menganalisis lebih lanjut unsur-unsur aporia yang ada di dalam suatu teks.

Dalam Novel Sitti Nurbaya: Kasih tak Sampai, Siti Nurbaya yang selama ini dicitrakan sebagai perempuan lemah dan hanya bisa pasrah menerima perjodohan antara dirinya dan Datuk Maringgih, seorang pria yang usianya jauh lebih tua dari dirinya ternyata dalam hati, pikirannya tersimpan pemikiranpemikiran yang menyimpang dari adat kebiasaan masyarakat Indonesia pada masa itu. Pemikiran-pemikiran dan perbuatan Siti Nurbaya yang tidak sesuai dengan adat kebiasaan pada masa itu merupakan bentuk dari dekonstruksi konsep perempuan.

Hal tersebut sesuai dengan pendapat Nasution (2016:180) bahwa orangtua merupakan pihak yang dominan dalam memilih dan menentukan jodoh anak perempuannya yang merupakan kaum tertindas di lingkungannya. Sikap orangtua yang mencarikan jodoh untuk anak perempuannya merupakan tradisi turun-temurun yang tertanam sebagai warisan masa kuno.

Pemikiran tersebut tentu tidak serta merta patut dipikirkan oleh seorang istri kepada suaminya. Seorang istri haruslah dapat menerima segala kelebihan dan kekurangan suaminya. Apa pun keadaan dan sikap suami, istri haruslah tetap menghormatinya. Hayati (2012:167) mendapati bahwa perempuan harus patuh dan setia merupakan label umum yang diberikan oleh masyarakat pada diri perempuan sedangkan laki-laki tidak diharuskan setia karena selalu saja ada pemakluman apabila seorang laki-laki 
mengkhianati istri atau pasangannya.

Pada masa novel tersebut ditulis, perempuan usia tiga belas tahun sudah banyak yang mulai menikah. Apabila di usia dua puluhan perempuan belum menikah, maka ia akan dianggap sebagai perawan tua. Fitrianingsih (2015:14) menengarai bahwa pernikahan di usia muda telah membudaya atau mentradisi, anggapan yang berkembang adalah harga diri keluarga dan keluarga perempuan akan jatuh apabila menikahkan anak perempuannya di usia tua sehingga takut tidak memiliki pasangan.

\section{Tabel 1 Diferensiasi Bentuk Konsep Perempuan pada Tiga Novel}

\begin{tabular}{|c|c|c|c|c|}
\hline \multirow{2}{*}{$\begin{array}{l}\text { Judul } \\
\text { Novel }\end{array}$} & \multirow{2}{*}{$\begin{array}{c}\text { Dekonstruksi Konsep } \\
\text { Perempuan }\end{array}$} & \multicolumn{3}{|c|}{ Unsur Aporia } \\
\hline & & Paradoks & Ironi & Kontradiksi \\
\hline $\begin{array}{l}\text { Sitti } \\
\text { Nurbaya }\end{array}$ & $\begin{array}{l}\text { - Perempuan menolak } \\
\text { perjodohan } \\
\text { - Perempuan mencerca } \\
\text { suaminya } \\
\text { - Perempuan tidak } \\
\text { seharusnya menikah di } \\
\text { usia muda } \\
\text { - Perempuan } \\
\text { berpendidikan }\end{array}$ & $\begin{array}{l}\text { - Siti Nurbaya } \\
\text { mencerca } \\
\text { suaminya }\end{array}$ & $\begin{array}{l}\text { - Siti Nurbaya } \\
\text { berharap } \\
\text { memiliki } \\
\text { kehendak } \\
\text { dan kekuatan } \\
\text { yang sama } \\
\text { dengan laki- } \\
\text { laki }\end{array}$ & $\begin{array}{l}\text { - Nurbaya } \\
\text { menentang } \\
\text { adanya } \\
\text { perjodohan } \\
\text { - Siti Nurbaya } \\
\text { menentang } \\
\text { pernikahan } \\
\text { perempuan di } \\
\text { usia muda }\end{array}$ \\
\hline Belenggu & $\begin{array}{l}\text { - Perempuan menggoda } \\
\text { laki-laki } \\
\text { - Perempuan } \\
\text { meninggalkan } \\
\text { suaminya } \\
\text { - Perempuan } \\
\text { berpengetahuan luas }\end{array}$ & $\begin{array}{l}\text { - Yah sosok } \\
\text { berpengetahuan } \\
\text { - Yah selalu ceria } \\
\text { meskipun hidup } \\
\text { menderita } \\
\text { - Perilaku Yah } \\
\text { yang terpelajar }\end{array}$ & $\begin{array}{l}\text { - Yah } \\
\text { meninggalkan } \\
\text { suaminya }\end{array}$ & $\begin{array}{l}\text { - Yah sosok } \\
\text { yang tangguh } \\
\text { - Yah } \\
\text { meninggalkan } \\
\text { Tono }\end{array}$ \\
\hline $\begin{array}{l}\text { Di Balik } \\
\text { Kerling } \\
\text { Saatirah }\end{array}$ & $\begin{array}{l}\text { - Perempuan bersuami } \\
\text { mengharapkan } \\
\text { perhatian dan kasih } \\
\text { sayang dari pria lain } \\
\text { - Perempuan bersuami } \\
\text { menjalin hubungan } \\
\text { terlarang dengan } \\
\text { pria lain di belakang } \\
\text { suaminya } \\
\text { - Perempuan bersuami } \\
\text { menjadi tulang } \\
\text { punggung keluarga } \\
\text { - Perempuan yang } \\
\text { menjadi perempuan } \\
\text { mandiri }\end{array}$ & $\begin{array}{l}\text { - Saatirah merasa } \\
\text { rindu dan } \\
\text { tertarik kepada } \\
\text { pria lain } \\
\text { - Saatirah, istri } \\
\text { yang bekerja } \\
\text { keras untuk } \\
\text { menghidupi } \\
\text { keluarganya } \\
\text { - Saatirah } \\
\text { bertindak tegas } \\
\text { pada sang } \\
\text { suami }\end{array}$ & $\begin{array}{l}\text { - Perasaan } \\
\text { cinta yang } \\
\text { tidak } \\
\text { seharusnya } \\
\text { dimiliki oleh } \\
\text { Saatirah } \\
\text { kepada pria } \\
\text { lain }\end{array}$ & $\begin{array}{l}\text { - Saatirah } \\
\text { mengkhianati } \\
\text { suaminya } \\
\text { - Saatirah } \\
\text { sosok yang } \\
\text { mandiri }\end{array}$ \\
\hline
\end{tabular}


Bentuk dekonstruksi konsep perempuan berikutnya yang tercermin dari pola pikir Siti Nurbaya yang menganggap bahwa pendidikan merupakan hal yang penting bagi perempuan agar tidak lagi diremehkan kaum laki-laki. Sayangnya, pemikiran Nurbaya itu tidaklah sejalan dengan pola pikir masyarakat saat itu. Bagi sebagian besar masyarakat, perempuan tidaklah harus berpendidikan tinggi karena pada akhirnya, perempuan hanya bertugas di rumah, bergelut dengan urusan dapur dan anak. Sejak kecil, perempuan telah dididik untuk mengurusi urusan rumah tangga. Hayati (2012:168) menegaskan bahwa perempuan tidak bisa menunjukkan keberadaan mereka selain hanya menjadi istri dan ibu bagi anakanak mereka yang secara tidak langsung memperkuat posisi mereka sebagai subordinat bagi laki-laki.

Menurut pemikiran Nurbaya, pendidikan penting untuk perempuan karena dapat menghindarkan perempuan dari tindakan kesewenang-wenangan laki-laki serta menghindarkan perempuan dari hinaan. Selain itu, pendidikan juga dapat menjadikan perempuan sebagai kaum yang mandiri sehingga dapat bekerja untuk memenuhi kehidupannya. Dengan demikian, hidup perempuan tidak hanya bergantung pada suaminya. Pemikiran Nurbaya tentulah sebuah pemikiran yang menentang konsep yang selama ini dipercayai oleh sebagian masyarakat Indonesia.

Menurut adat istiadat pada masa itu, perempuan haruslah berada di rumah, menyiapkan segala kebutuhan suami dan keluarganya, bukan bekerja di luar ruar rumah. Kaum laki-lakilah yang berkewajiban mencari nafkah dengan bekerja dan untuk menghidupi keluarganya. Ideologi patriarki mencirikan bahwa laki-laki merupakan kepala rumah tangga baik sebagai pencari nafkah yang terlihat dalam pekerjaan produktif di luar rumah maupun sebagai penerus keturunan (Sihite, 2007:54). Hal senada diungkapkan pula oleh Krisnalita (2018:78) bahwa struktur keluarga tradisional telah menciptakan pembagian hak, kewajiban, waktu, dan nilai yang berbeda kepada setiap anggota keluarga, laki-laki diletakkan pada posisi puncak yang mengurusi segala pekerjaan di luar rumah sedangkan perempuan berada di bawah kendali laki-laki yang mengurusi segala urusan domestik.

Jika Nurbaya hanya berhenti pada pemikiran tanpa dapat mewujudkannya dalam sebuah tindakan, maka Rohayah atau Yah dalam novel Belenggu menciptakan gambaran yang berbeda mengenai sosok perempuan. Melalui perilaku dan tindakannya, citra perempuan dibongkar dan didekonstruksi. Rohayah memiliki keberanian yang lebih besar daripada Siti Nurbaya. Hal itu terbukti dari tindakan yang dilakukan oleh Rohayah. Jika Nurbaya hanya berani untuk berpikir tanpa bertindak, Rohayahlah yang mewujudkannya dalam tindakan. Bentuk dekonstruksi konsep perempuan dalam diri Rohayah yang kedua tercermin melaluitindakannya ketika meninggalkan sang suami. Bentuk dekonstruksi konsep perempuan berikutnya yang tercermin dalam diri Rohayah dapat terlihat dari sosok Rohayah yang memiliki pengetahuan luas. 
Hal itu sangat bertolak belakang dengan kebanyakan perempuan lain yang berpengetahuan rendah dan tidak memiliki kedalaman pemikiran. Hal tersebut sesuai dengan pendapat Zuhriyah (2018:252) bahwa masyarakat di negara berkembang menganggap bahwa perempuan tidaklah memerlukan pendidikan tinggi karena tugas perempuan hanya berhenti pada wilayah domestik saja. Oleh karena itu, masyarakat menomerduakan pendidikan bagi kaum perempuan. Namun, Rohayah memiliki pandangan yang berbeda, ia banyak menghabiskan waktunya dengan membaca buku sehingga ia berwawasan luas, salah satu hal yang langka ditemukan pada perempuan-perempuan Indonesia masa itu.

Selain sosok Siti Nurbaya dan Rohayah ada pula sosok Saatirah yang dapat ditemukan pada novel $D B K S$. Kepribadian dan perilaku yang ditunjukkan oleh Saatirah membongkar citra perempuan pada umumnya hingga ke akarnya. Melalui sosok Saatirah, perempuan benar-benar direkonstruksi ulang seperti sebuah bangunan yang dihancurkan hingga ke fondasinya untuk kembali dibangun dengan bangunan berarsitektur baru. Melalui sosok Saatirah dalam novel $D B K S$ dapat ditemukan sebuah rekonstruksi perempuan dengan pemikiran-pemikiran modern, perilaku yang lebih bebas dalam berekspresi dan bertindak, serta berkepribadian yang kuat.

Perilaku yang demikian mencederai citra perempuan sebagai sosok yang setia. Dalam masyarakat, seorang perempuan yang telah bersuami mengharapkan kasih sayang dan perhatian dari pria lain diangggap sebagai suatu hal yang tidak pantas dan tidak wajar. Meskipun ada, perempuan tersebut akan diberi label sebagai perempuan murahan. Hal itu akan berbeda apabila seorang suami yang melakukannya karena jarang sekali dalam masyarakat menggunakan pelabelan pada pria dengan menyebut "pria murahan".

Pengharapan Saatirah untuk mendapatkan perhatian dan kasih sayang dari pria lain meruntuhkan pandangan patriarki bahwa perempuan haruslah tunduk kepada suaminya dan menjaga martabat sang suami serta mengabdikan hidupnya untuk memberikan kebahagian kepada sang suami.

Jika perempuan yang melakukan perselingkuhan maka masyarakat akan memandangnya sebagai perempuan rendahan dan menghujatnya, namun berbeda halnya dengan pria. Jika pria yang melakukan perselingkuhan, masyarakat akan menganggapnya sebagai suatu hal yang biasa dan bukan merupakan fenomena yang mengherankan. Hal ini sama halnya dengan istilah playboy yang sering sekali digunakan dalam kehidupan sosial sedangkan istilah playgirl jarang sekali terdengar meskipun sebenarnya ada.

Demikian pula halnya, seorang istri yang bekerja dianggap suatu hal yang juga tidak biasa lebih-lebih bila ia merupakan tumpuan keuangan keluarganya. Dalam masyarakat, umumnya suamilah yang menjadi tulang punggung keluarga, bekerja keras untuk mencari nafkah bagi keluarganya. Hal serupa diungkapkan oleh Hardiansyah (2018:251) bahwa dalam menjalin hubungan keluarga, seorang pria 
bertanggung jawab untuk membiayai dan menanggung kebutuhan hidup keluarganya.

Tentu saja hal ini berbeda dengan kondisi yang dialami Nurbaya dan Rohayah. Pada masa itu perempuan belum banyak yang bekerja di sektor formal. Apabila ada perempuan yang bekerja pun pekerja kasar seperti menjadi pembantu dan buruh tani karena pada saat itu sebagian besar perempuan hanya berpendidikan rendah sehingga membuat perempuan sulit untuk mendapatkan pekerjaan. Hal tersebut telah disimpulkan Haslinda (2017:98) bahwa keterbatasan peluang kerja perempuan berkaitan erat dengan modal yang dimiliki oleh tenaga kerja perempuan yang secara umum dapat dikatakan human capital perempuan yang meliputi pendidikan, latihan, dan pengalaman yang relatif masih rendah.

Perilaku dan kepribadian Saatirah yang demikian itu tentu saja tidak lepas dari perkembangan zaman yang semakin hari menuju arah yang lebih baik untuk kehidupan perempuan. Berdasarkan data publikasi dari Kementrian Pemberdayaan Perempuan dan Perlindungan Anak Republik Indonesia tahun 2018 di Indonesia pembelaan terhadap kesetaraan gender mulai intensif dilakukan sejak adanya Konvensi Penghapusan segala Bentuk Diskriminasi terhadap Perempuan, adopsi PBB tahun 1979 untuk melindungi hak-hak perempuan yang disahkan pada tanggal 3 September 1981. Hal itu telah menjadikan Indonesia 1 dari 189 negara yang menandatangani hasil konvensi tersebut pada tanggal 29 Juli 1980. Baru kemudian di tanggal 13 September 1984, Indonesia meratifikasinya melalui Undang-Undang
Nomor 7 Tahun 1984 tentang pengesahan Konvensi Penghapusan segala Bentuk Diskriminasi terhadap Wanita. Oleh karena itu, tidak mengherankan jika novel-novel yang lahir di atas tahun 80an sudah banyak yang mulai bebas dan luas dalam merekonstruksi sosok perempuan.

Secara garis besar ketiga novel tersebut sama-sama memberikan gambaran yang berbeda tentang perempuan. Secara umum, perbedaan ketiga novel tersebut terletak pada konsep dekonstruksi yang diusung. Pada Novel Sitti Nurbaya: Kasih tak Sampai dekonstruksi berupa pemikiranpemikiran yang ada di dalam kepala perempuan. Hal tersebut berbeda dengan yang terdapat di dalam novel Belenggu, pada novel ini dekonstruksi tergambar melalui tindakan-tindakan yang dilakukan oleh tokoh perempuan. Pada novel DBKS dekonstruksi konsep perempuan tecermin melalui perilaku dan kepribadian tokoh perempuan.

Ketiga perbedaan konsep dekonstruksi tersebut dapat dipengaruhi oleh beberapa faktor, salah satunya faktor lingkungan. Novel Sitti Nurbaya: Kasih tak Sampai merupakan novel yang pertama kali dirilis pada tahun 1922, novel Belenggu merupakan novel yang pertama kali dirilis pada tahun 1940, dan novel $D B K S$ pertama kali dirilis pada tahun 2010. Berdasarkan tahun perilisan, ketiga novel tersebut mempunyai perbedaan waktu yang cukup jauh.

Pada masa penjajahan Belanda, perempuan dianggap sebagai kaum yang rendah dan lemah sehingga selalu menjadi sasaran utama penindasan. Hellwig (2007:24) mengatakan bahwa 
pada masa penguasaan Hindia-Belanda perempuan dianggap lebih rendah daripada pria sekalipun kaum perempuan memegang peranan penting dalam pembudidayaan padi serta tanamantanaman lainnya. Pada masa penjajahan perempuan hanya dijadikan sebagai pemuas laki-laki. Di dalam keluarga perempuan tidak mempunyai hak suara, segala keputusan dipegang oleh laki-laki. Nasution (2016:190) berpendapat bahwa sejak zaman kolonial perempuan sudah dijadikan pemuas nafsu laki-laki. Kebiasaan laki-laki yang selalu mementingkan keperluannya sendiri tanpa memedulikan perasaan perempuan tanpa disadari sudah menindas kaum perempuan.

Pada masa itu, budaya patriarki masih sangatlah kental dalam masyarakat Indonesia dan hanya membawa penderitaan untuk kaum perempuan. Sakinah dan Siti (2017:72) menegaskan bahwa dalam masyarakat patriarki lakilaki berperan sebagai kontrol utama sedangkan perempuan tidak memiliki hak pada wilayah-wilayah umum dalam masyarakat, baik secara ekonomi, sosial, politik, dan psikologi bahkan termasuk dalam ranah kehidupan pernikahan. Perempuan seolah tidak memiliki wewenang apa pun bahkan untuk menentukan kehidupannya sendiri, perempuan menjadi pihak inferior dan laki-laki adalah pihak superior. Kekuasaan patriarki menjadi mata rantai dari kekuatan maskulinitas laki-laki yang membentuk satu stigma untuk membelenggu kaum perempuan ketika menjalin hubungan dengan kaum lakilaki.

\section{Unsur Aporia: Paradoks, Ironi, dan Kontradiksi}

Selain perbedaan dekonstruksi konsep perempuan, di dalam ketiga novel tersebut ditemukan pula unsur-unsur aporia berupa paradoks, ironi, dan kontradiksi. Unsur aporia pertama yang terdapat di dalam Novel Sitti Nurbaya: Kasih tak Sampai adalah paradoks yang tercermin dari sikap Siti Nurbaya yang sama sekali tidak mau menunjukkan rasa hormat pada suaminya.

Pada sosok Rohayah dalam novel Belenggu, paradoks pertama dapat ditemukan dari sikap Rohayah yang berpengetahuan dan berwawasan luas. Menurut sebagian masyarakat saat itu perempuan berpengetahuan luas dan berpendidikan bukanlah hal yang baik karena dengan pengetahuan yang dimilikinya, menyebabkan seorang perempuan menentang suaminya.

Hal tersebut tentu saja sangat berbeda dengan kebanyakan perempuan bersuami pada masa itu yang menghabiskan waktunya hanya mengurusi urusan rumah tangga sebagaimana dikatakan oleh Nasution (2016:161) bahwa seorang istri memiliki tugas untuk selalu melayani suami dan mengurus anak-anaknya. Selain itu istri juga harus mampu mendampingi suami dalam segala keadaan dan menerima segala kekurangan yang dimiliki suaminya.

Paradoks kedua yang ditemukan dalam novel Belenggu tercermin dari tindakan Rohayah yang meninggalkan suaminya, paradoks ketiga tergambar dari sosok Rohayah yang selalu terlihat ceria. Perempuan yang selama ini dicitrakan berhati lembut, rapuh, dan tergambar sebagai sosok yang lemah 
dalam lingkungan masyarakat dapat ditentang oleh Rohayah. Sosok Rohayah menampilkan citra perempuan yang berbeda dari yang saat itu diyakini oleh sebagian besar masyarakat.

Paradoks pertama dalam novel $D B K S$ terlihat dari sikap Saatirah yang merupakan perempuan bersuami, namun merasakan kerinduan mendalam pada pria lain dan merasa cemas jika pria itu tidak menghubunginya. Hal ini tidak sesuai dengan kejadian atau situasi yang diyakini oleh lingkungan masyarakat karena seorang istri seharusnya dapat menjaga hatinya, sehingga yang patut dirindukan dan dicemaskannya adalah suaminya bukan pria lain. Selain itu, Saatirah juga berharap untuk mendapat kasih sayang dari Tora, sementara seharusnya Saatirah sebagai seorang istri hanya menerima kasih sayang yang diberikan oleh suaminya.

Paradoks kedua tergambar melalui sosok Saatirah sebagai seorang istri yang bekerja keras membanting tulang untuk membayar hutang-hutang suaminya dan membiayai kehidupan keluarganya. Hal tersebut tentu saja bertolak belakang dengan pandangan umum yang menganggap bahwa dalam kehidupan berumah tangga harusnya suamilah yang menjadi tulang punggung keluarga dan menanggung segala kebutuhan hidup keluarganya bukan istri. Hal serupa diungkapkan oleh Hadiansyah (2018:251) bahwa dalam menjalin hubungan keluarga, seorang pria bertanggung jawab untuk membiayai dan menanggung kebutuhan hidup keluarganya.

Unsur aporia kedua yang terdapat di dalam ketiga novel beda zaman adalah ironi. Ironi pada ketiga novel tersebut terletak pada kondisi batin yang dialami Siti Nurbaya, situasi lingkungan masyarakat tempat Rohayah tinggal, dan perasaan yang dirasakan oleh Saatirah.

Adanya persamaan kekuatan antara laki-laki dan perempuan dapat meminimalkan tindak kekerasan dalam rumah tangga yang banyak dilakukan oleh suami kepada istrinya. Pemikiran dan harapan Nurbaya yang demikian tentu saja bertentangan dengan situasi atau keadaan yang saat itu terjadi di lingkungan masyarakat Indonesia, terutama masyarakat pedesaan. Pada masa itu, masyarakat pedesaan sangat menjunjung nilai-nilai luhur warisan nenek moyang mereka sehingga perempuan masih dianggap kaum yang derajatnya rendah. Hermawati (2007:19) mengatakan bahwa dalam masyarakat laki-laki derajatnya dipandang lebih tinggi daripada perempuan yang menyebabkan kaum laki-laki menjadi pihak yang berkuasa, akhirnya perempuanlah menjadi korban karena dianggap memiliki derajat di bawah lakilaki

Jika Nurbaya hanya dapat memendam harapannya di dalam hati dan tersimpan dalam pikirannya, hal berbeda dilakukan oleh Rohayah. Ia dengan berani menentang norma masyarakat yang memperlakukan perempuan sebagai pihak yang disetir bukan yang menyetir.

Perbuatan Rohayah tersebut sangatlah bertentangan dengan harapan yang ditanamkan oleh orangtuanya dan masyarakat sekitar tempat tinggal. Orangtua Rohayah tentulah sangat berharap agar anak perempuannya itu dapat hidup damai dan bahagia dengan suaminya. Rohayah diharapkan dapat 
menjadi istri yang berbakti dan dapat melayani suaminya dengan sepenuh hati. Namun sayang, hal sebaliknyalah yang terjadi sebagaimana dikatakan oleh Anisa dan Indiatmoko (2017:81) bahwa seorang istri hendaknya selalu melayani suami dan menyiapkan segala kebutuhannya. Saat suami pulang kerja hendaknya seorang istri menyambut suaminya dengan wajah yang berseri dan menyiapkan makan malam yang disukai suaminya.

Ironi juga ditemukan melalui sosok Saatirah yang merasakan kerinduaan kepada pria lain bukan kepada suaminya. Saatirah merupakan seorang istri yang diharapkan dapat setia kepada suaminya dan dapat menjaga hati untuk tidak tertarik kepada pria lain, namun ia melakukan hal yang sebaliknya. Meskipun Saatirah juga berharap dapat menjaga hatinya hanya untuk Andro, namun pada kenyataannya ia juga mencintai pria lain.

Perasaan rindu yang dirasakan Saatirah diwujudkannya melalui pertemuan-pertemuan dengan Tora yang mengindikasikan bahwa Saatirah bukanlah istri yang setia. Sebagai seorang istri seharusnya Saatirah dapat mengontrol perasaan dan menjaga kesetiaannya. Hal serupa diutarakan pula oleh Hariwijaya (2004:75) bahwa seorang istri dituntut untuk setia dan menjalani empat hal, yaitu pawon, paturon, pangreksa, dan harus menghindari padudon. Artinya, seorang istri haruslah dapat mengabdikan kehidupannya untuk sang suami baik di dapur, di ranjang, di dalam pengelolaan rumah tangga, dan ketika sang suami sedang dalam keadaan emosi yang labil, seorang istri haruslah mampu menjadi pendamping yang menenangkan jiwa dan mengalah di depan sang suami.

Unsur aporia ketiga yang terdapat di dalam ketiga novel tersebut adalah kontradiksi. Kontradiksi dalam ketiga novel terletak pada tindakan yang dilakukan oleh Nurbaya, Rohayah, dan Saatirah yang tidak sesuai atau bertentangan dengan pemikiran yang mengendap dalam pikiran kedua tokoh perempuan tersebut. Nurbaya merupakan sosok perempuan yang menikah karena dijodohkan oleh ayahnya. Menikah dengan cara perjodohan merupakan tindakan yang ditentang oleh Nurbaya.

Perjodohan adalah hal yang bertolak belakang atau kontradiktif dengan jalan pikiran Nurbaya. Selain menentang perjodohan, Nurbaya merupakan sosok perempuan yang menganggap bahwa pernikahan perempuan di usia muda bukanlah hal yang baik. Oleh karena itu, ia berharap agar masyarakat menghentikan tradisi pernikahan dini pada masa itu. Namun, pemikiran Nurbaya tersebut sayangnya tidak sejalan atau bertolak bertentangan dengan jalan hidup Nurbaya. Selain menjadi perempuan korban perjodohan, ia juga merupakan perempuan yang dinikahkan pada saat usia muda.

Hal serupa pun terjadi pada sosok Rohayah. Pada satu sisi Rohayah dicitrakan sebagai seorang perempuan yang tangguh, selalu berpikiran positif, dan tidak mudah panik saat mengambil keputusan, namun ternyata di sisi lain ia juga menyimpan kekhawatiran dalam hatinya. Bayang-bayang masa lalu yang penuh dengan lembaran kelam membuat hidup Rohayah tidak tenang. Hal itu pula 
yang menyebabkan Rohayah mengambil keputusan untuk meninggalkan Tono, laki-laki yang sangat dicintainya.

Perbuatan Rohayah yang meninggalkan Tono sangatlah bertolak belakang dengan keinginan hati Rohayah yang selalu ingin dekat dengan Tono dan mengharapkan cinta Tono seutuhnya. Perbuatan Rohayah yang bertolak belakang dengan keinginan hatinya dan perjuangannya selama ini untuk mendapatkan Tono merupakan akibat dari ketakutan Rohayah tentang masa lalunya yang kelam sehingga dikhawatirkan membuat nama baik Tono tercemar dan Tono mendapat cemoohan orang.

Kontradiksi dalam novel DBKS tercermin melalui perilaku Saatirah yang mengkhianati sang suami, ia melakukan perselingkuhan dengan laki-laki yang lebih muda darinya. Semua hal tersebut dilakukan tanpa sepengetahuan sang suami. Perselingkuhan yang dilakukan Saatirah bertolak belakang dengan usahanya yang selalu ingin terlihat menarik di depan sang suami agar sang suami tetap mencintainya. Perilaku Saatirah yang demikian dapat diindikasikan bahwa kemungkinan ia menginginkan dua laki-laki dalam hidupnya. Di satu sisi ia ingin sang suami mencintainya dengan sepenuh hati, namun di sisi lain ia juga tetap menjalin hubungan dengan laki-laki lain. Keadaan tersebut tentu sangatlah tidak sejalan dengan norma masyarakat yang melarang seorang perempuan memiliki dua lakilaki dalam kehidupannya.

Selain itu, kontradiksi juga terlihat dari kepribadian Saatirah. Saatirah yang memiliki kepribadian mandiri tergambar melalui perilakunya yang tidak manja, selalu pergi kemana-mana sendiri, mempunyai pekerjaan dengan penghasilan tetap, apabila ada masalah ia memendamnya sendiri dan berusaha menyelesaikan masalah tersebut dengan caranya sendiri. Hal tersebut sangatlah bertolak belakang dengan pandangan masyarakat bahwa perempuan adalah kaum yanglemah sehingga membutuhkan perlindungan laki-laki. Hal tersebut sesuai dengan pendapat Nasution (92:2016) bahwa perempuan merupakan makhluk yang lemah, membutuhkan penolong/pelindung, cengeng, emosional, dan berkedudukan sebagai penerima perintah.

Melalui Novel Sitti Nurbaya: Kasih tak Sampai, MarahRusliinginmenyampaikan sesuatu yang berbeda. Hal yang sama dilakukan pula oleh Armijn Pane melalui novel Belenggu, ia berusaha untuk menampilkan sosok perempuan yang berbeda dari biasanya. Begitu pula yang dilakukan Ninik M. Kuntarto pada sosok Saatirah dalam novel $D B K S$, ia berusaha untuk menghancurkan citra perempuan kuno dan menggantinya menjadi citra perempuan modern.

Ketiga pengarang tersebut mengobrak-abrik pemikiran yang selama ini telah berkembang di masyarakat. Baik Marah Rusli, Armijn Pane, dan Ninik M. Kuntarto sama-sama berusaha untuk melakukan pendekonstruksian terhadap sosok perempuan. Perbedaannya terletak pada konsep pendekonstruksian yang dilakukan. Marah Rusli mendekonstruksi sosok perempuan melalui pemikiranpemikiran yang tidak semestinya dimiliki oleh perempuan sedangkan Armijn Pane mendekonstruksi perempuan melalui 
tindakan-tindakan yang tidak seharusnya dilakukan oleh seorang perempuan. $\mathrm{Hal}$ itu karena pemikiran dan tindakan tersebut tidaklah sesuai dengan normanorma yang diyakini oleh sebagian besar masyarakat. Melalui sosok Saatirah, Ninik M. Kuntarto mendekonstruksi perempuan melalui pemikiran, Tindakan dan perilaku yang sangat berbeda dengan yang selama ini terkonsep dalam pemikiran masyarakat.

\section{SIMPULAN}

Perempuan yang terwakili melalui tokoh utama ketiga novel yang berlatar waktu yang berbeda pada masa diciptkan novel, dianggap sebagai kaum yang lemah dan rendah telah mendapatkan banyak perlakuan yang tidak adil dari kaum laki-laki. Pada saat itu kaum lakilaki dianggap sebagai kaum superior sedangkan perempuan dianggap sebagai kaum inferior yang menyebabkan banyak terjadi kasus kekerasan pada perempuan. Melalui Novel Sitti Nurbaya: Kasih tak Sampai, Belenggu, dan DBKS, Marah Rusli, Armijn Pane, dan Ninik M. Kuntarto berusaha untuk mendekonstruksi sosok perempuan yang terkonsep dalam pemikiran sebagian besar masyarakat Indonesia sebagai kaum minoritas yang kehadirannya dianggap hanya sebagai pemuas kebutuhan laki-laki.

Meskipun ketiga pengarang tersebut sama-sama berusaha untuk mendekonstruksi sosok perempuan, namun terdapat perbedaan konsep dalam pendekonstruksian yang dilakukan. Pada Novel Sitti Nurbaya: Kasih tak Sampai pendekonstruksian terhadap perempuan yang dilakukan oleh pengarang hanya sebatas pemikiran-pemikirannya saja. Pendekonstruksian yang lebih kompleks terdapat di dalam novel Belenggu, dekonstruksi terhadap perempuan tidak hanya terbatas pada pemikiran, tetapi juga tindakan-tindakan yang dilakukan. Pendekonstruksian yang lebih komprehensif dan dalam terdapat di dalam novel $D B K S$ yang tecermin melalui perilaku, sikap, dan kepribadian Saatirah. Dalam ketiga novel tersebut juga terdapat unsur aporia yang berupa paradoks, ironi, dan kontradiksi yang menjadi dasar pendekonstruksian sosok perempuan baik berupa dekonstruksi pemikiran, tindakan, sikap, maupun kepribadian.

\section{DAFTAR PUSTAKA}

Afdholy, N. (2019). Dekonstruksi Makna Jihad dalam Novel Laskar Mawar Karya Barbara Victor. Lingua Franca: Jurnal Bahasa, Sastra, dan Pengajarannya, 3(1), 24-51. DOI: http://dx.doi.org/10.30651/ 1f.v3i1.2586.

Alfayyadl, M. (2012). Derrida. Yogyakarta: LKiS.

Andira, S. R. (2016). Unsur-Unsur Aporia dalam Novel Pulang Karya Leila S. Chudori (Suatu Pendekatan Dekonstruksi Jacques Derrida). Jurnal Fakultas Bahasa dan Sastra Universitas Negeri Makassar, 1-23. Http://eprints.unm.ac.id/6470/.

Anisa , A. I, dan Bambang I. (2017). Representasi Sistem Pernikahan Budaya Yogya dalam Novel Perempuan Jogja Karya Achmad Munif. Seloka: Jurnal Pendidikan Bahasa dan Sastra Indonesia, 6(1), 7484. https://journal.unnes.ac.id/sju/ 
index.php/seloka/article/ view/14768.

Arisandy, A. (2018). Anasis Dekonstruksi Tokoh Utama Satar dalam Novel Sabda dari Persemayaman Karya T.M. Dhani Iqbal: Perspektif Jacques Derrida. Jurnal Fakultas Bahasa dan Sastra Universitas Negeri Makassar, 1-10. http://eprints.unm.ac. id/10496/.

Fatmawati, I. (2017). Dekonstruksi Tokoh Kunci Pada Novel Laskar Pelangi. Jurnal Pendidikan, 3, 31-49.

Fitrianingsih, R. (2015). Faktor-faktor Penyebab Pernikahan Usia Muda Perempuan Desa Sumberdanti Kecamatan Sukowono Kabupaten Jember [Skripsi]. Jember (ID): Universitas Jember.

Hayati, Y. (2012). Representasi Ketidakadilan Gender dalam Cerita dari Blora Krya Pramoedya Ananta Toer: Kajian Feminisme. Jurnal Atavisme. 15(2):163-176. https://doi. org / $10.24257 /$ a tavis me. v15i2.57.163-176.

Hadiansyah, D. (2018). Falsafah Keluarga. Jakarta: PT Elex Media Komputindo.

Hariwijaya. (2004). Seks Jawa Klasik. Yogyakarta: Niagra.

Haslinda. (2017). Partisipasi Perempuan dalam Dunia Pariwisata. Jurnal An Nisa', 10(1), 92-98. DOI: 10.30863/ annisa.v10i1.387.

Hendrawansyah. (2018). Paradoks Budaya: Tinjauan Strukturalisme Genetik Goldman. Ponorogo: Uwais Inspirasi Indonesia.

Hellwig, T. (2007). Citra Kaum Perempuan di Hindia-Belanda. Jakarta: Yayasan Obor Indonesia.
Hidayat, W. N. (2009). Filsafat Bahasa. Yogyakarta: As Books.

Kementrian Pemberdayaan Perempuan dan Perlindungan Anak Republik Indonesia. (2018). Data Publikasi Gender dan Perjalanan Indonesia Menuju Kesetaraan. Jakarta.

Krisnalita, L. Y. (2018). Perempuan, HAM, dan Permasalahannya di Indonesia. Jurnal Binamulia Hukum, 7 (1),71-81.https://doi.org/10.37893/ jbh.v7i1.15.

Kurniawan. (2001). Semiologi Roland Barthes. Magelang: Penerbit Yayasan Indonesiatera.

Kusumawati, H. (2016). Dekonstruksi Konsep Cantik Perempuan Madura dalam Kumpulan Puisi Nemor Kara Karya Penyair Madura. Jurnal Gender dan Budaya Madura, 3: 223-227. https://1ppm.trunojoyo.ac.id/ budayamadura /wp-content / uploads/2016/10/2-33.-ARTIKEL. pdf.

Lechte, J. (2001). 50 FilsufKkontemporer: dari Strukturalisme sampai Postmodernitas. Yogyakarta: Penerbit Kanisius.

Nasution, R. (2016). Ketertindasan Perempuan dalam Tradisi Kawin Anom: Subaltern Perempuan pada Suku Banjar dalam Perspektif Poskolonial. Jakarta: Yayasan Obor Indonesia.

Nasution, N. T. W. (2016). Representasi Diskriminasi terhadap Perempuan dalam Film Khalifah [Skripsi]. Yogyakarta (ID): Universitas Islam Negeri Sunan Kalijaga.

Pane, A. (1940). Belenggu. Jakarta: Dian Rakyat.

Royle, N. (2003). Derrida. London: Routledge. 
Rusli,.M. (1922). Siti Nurbaya: Kasih tak Sampai. Jakarta: Balai Pustaka.

Sakina, A. I, dan Dessy H. S. 2017. Menyoroti Budaya Patriarki di Indonesia. Social Work Joernal, 7(1), 71-80. DOI : https://doi. org/10.24198/share.v7i1.13820.

Sarup, M. (2011). Posstrukturalisme dan Posmodernisme: Sebuah Pengantar Kritis. Yogyakarta: Jendela.

Setyawati, I. (2020). Dekonstruksi Tokoh dalam Novel Setiyana Karya Cok Sawitri (Kajian Dekonstruksi Jacques Derrida). Jurnal Bapala, 7(1), 1-12. https://ejournal.unesa.ac.id/index. $\mathrm{php} / \mathrm{bapala} / \mathrm{article} / \mathrm{view} / 33423$.

Sihite, R. (2007). Perempuan, Kesetaraan dan Keadilan: Suatu Tinjauan Berwawasan Gender. Jakarta: PT Raja Grafindo Persada.
Sugiharto, B. (1996). Postmodernisme: tantangan bagi filsafat. Yogyakarta: Penerbit Kanisius.

Warsiman. (2016). Membumikan Pembelajaran Sastra yang Humanis. Malang: UB Press.

Wellek, R dan Warren, A. (2014). Teori Kesusastraan. Jakarta: Gramedia.

Zuhriyah, L. (2018). Perempuan, Pendidikan, dan Arsitek Peradaban Bangsa. Martabat: Jurnal Perempuan dan Anak, 2(2), 249-268. https://doi. o $\mathrm{r}$ g / $10 \begin{array}{ccccccc} & 0 & 2 & 2 & 7 & 4 & \text { / }\end{array}$ martabat.2018.2.2.249-268. 